\title{
Retinal vasculitis in Susac syndrome: case report
}

\author{
Vasculite retiniana na síndrome de Susac: relato de caso
}

\author{
Gherusa Helena Milbratz ${ }^{1}$ \\ Francisco Azevedo Marquardt ${ }^{2}$ \\ Heriberto Pinto Guimarães Neto ${ }^{3}$ \\ Daniel Azevedo Marquardt ${ }^{4}$ \\ Eduardo Soares Maia Vieira de Souza ${ }^{5}$
}

\begin{tabular}{|l|}
\hline ABSTRACT \\
\hline A 29 year old male was admitted at the emergency room suffering from \\
gradually worsening headache followed by nausea. In the hospital \\
patient presented with lethargy, reduction of consciousness level and \\
bilateral hypoacusis. Ophthalmic examination and fluorescein angio- \\
graphy showed retinal vasculitis. This finding was crucial to the diag- \\
nosis of Susac syndrome, a rare disease characterized by vasculopathy \\
of retina, encephalic tissues and cochlea. Patient was treated with \\
immunosuppressors to prevent him from developing severe sequelae \\
of this disease.
\end{tabular}

Keywords: Retinal vasculitis; Fluorescein angiography; Vasculitis, central nervous system; Hearing loss, sensorineural; Case reports [Publication type]

\section{INTRODUCTION}

Susac syndrome is a rare disease characterized by microangiopathy involving the arterioles of the brain, retina and cochlea. Encephalopathy, recurrent multiple retinal arterial occlusion and hearing loss, without systemic manifestation, are observed in healthy people of middle age, predominantly women ${ }^{(1)}$. This syndrome was first described by Susac et al. in $1979^{(2)}$, and since then less than 100 cases were reported in the literature worldwide. In Brazil, Skacel et al. first described it in $2000^{(3)}$ at a neuropsiquiatric journal, and our search could not find any reference of this syndrome in a Brazilian ophthalmologic journal.

It is believed that Susac syndrome is frequently underdiagnosed and usually misdiagnosed as multiple sclerosis or acute disseminated encephalomyelitis ${ }^{(4)}$. The ophthalmic evaluation is important for correct diagnosis, enabling prompt and appropriate therapy to avoid dreaded sequelae ${ }^{(5)}$.

Hospital Governador Celso Ramos - Florianópolis (SC) - Brazil.

${ }^{1}$ Ophthalmology Resident of Hospital Governador Celso Ramos - Florianópolis (SC) - Brazil.

${ }^{2}$ Ophthalmology Resident of Hospital Governador Celso Ramos - Florianópolis (SC) - Brazil.

${ }^{3}$ Ophthalmology Resident of Hospital Governador Celso Ramos - Florianópolis (SC) - Brazil.

${ }^{4}$ Ophthalmology Resident of Hospital Governador Celso Ramos - Florianópolis (SC) - Brasil.

${ }^{5}$ Ophthalmologist of Hospital Governador Celso Ramos - Florianópolis (SC) - Brazil.

Address for correspondence: Gherusa Helena Milbratz. Rua Irmã Benwarda, 297 - Florianópolis (SC) CEP 88015-270

E-mail: gherusa1983@yahoo.com.br

Recebido para publicação em 06.06.2008

Última versão recebida em 15.12.2008

Aprovação em 20.12.2008 \begin{tabular}{l} 
CASE REPORT \\
\hline In November of 2007 a 29 year old male, previously healthy, was admitted \\
at the neurology service of Santa Catarina Federal University Hospital. He \\
was, for ten consecutive days, suffering from gradually worsening heada- \\
ches followed by nausea and vomiting. During medical investigation the \\
patient presented with lethargy, reduction of consciousness level and bi- \\
lateral hypoacusis. \\
Patient did not match clinical and serologic criteria of connective tissue \\
diseases and there were no evidences of microembolism or coagulopathies. \\
After excluding viral imunomediated disorders, the neurology service sus- \\
pected of Susac syndrome. Magnetic nuclear resonance, with intravenous \\
contrast, demonstrated hyperintense injury in corpus callosum with distinctive \\
vessels suggesting a diagnosis of vasculitis. Brain evoked reflex auditory exam
\end{tabular} 
(BERA) demonstrated bilateral absence of electrophysiological threshold at $120 \mathrm{~dB}$ SPL, between 2000 and $4000 \mathrm{~Hz}$.

There was no complaint of visual loss, however patient's level of consciousness didn't allow measurement of visual acuity. On ophthalmic examination, fundus image suggested retinal vasculitis. Fluorescein angiography was performed in Governador Celso Ramos Hospital and showed focal arteriolar narrowing with areas of occlusion, vessel wall hyperfluorescence, and contrast outflow, characterizing retinal vasculitis (Figures 1A and B). Visual field exam was normal.

For treatment, the neurology service used pulse corticosteroid therapy with $1 \mathrm{~g}$ of methylprednisolone IV once a day for five days followed by $30 \mathrm{mg}$ of immunoglobulin IV once a day for three days. Patient demonstrated improvement of his consciousness level and remained without visual complaints, but his hearing loss persisted. As an outpatient, he was maintained on treatment with prednisone and cyclophosphamide.

Two months later a new fluorescein angiography was performed and showed improvement on retinal vasculitis, but persistent focal arterial occlusions, yet with no contrast outflow (Figures 2A, B and C). After three months of treatment, the patient had no ophthalmic complaints and no others neurological symptoms except hypoacusis.

\section{DISCUSSION}

Susac syndrome was named in reference to the description by John O. Susac in 1979 of two women who presented the classical clinical triad of encephalopathy, retinal arteriolar branch occlusions, and deafness ${ }^{(2)}$. Other authors have suggested the acronyms RED-M: retinopathy, encephalopathy, deafness associated microangiopathy and SICRET: small in- farcts of cochlear, retinal, and encephalic tissues ${ }^{(1)}$. Retinocochleocerebral vasculopathy is another name used for this syndrome that affects predominantly woman (3:1) ranging from 16 to 58 years old ${ }^{(6)}$. The initial symptoms are headache, often severe, followed by cognitive changes, confusion, and memory and psychiatric disturbance due to encephalopathy. Visual impairment is present in different levels depending on the retinal arterial branch affected. Hearing loss due to cochlear involvement completes the triad ${ }^{(7)}$. Sometimes the triad may become complete only after a delay of weeks to years. Its frequency is unknown and usually presents with a monophasic self-limited course lasting from months to years, however polycyclic and chronic courses are also related ${ }^{(8)}$. Although some patients recover with little or no residual disease, others are deeply impaired with cognitive deficits, gait disturbance and hearing loss. No deaths were reported so far ${ }^{(1-2,5-6)}$.

Etiology and pathogenesis of this microangiopathy are still not completely understood. Brain biopsies, anatomic observations and responses to immunosuppressive therapy suggest that the disease has an autoimmune basis, leading to small vessel vasculitis causing microinfarcts in retina, brain and in the apical turn of the cochlea. Vasospastic arterial occlusions and microembolizations seem unlikely. The distribution of arteriolar disease affecting brain, eye and ear is also an enigma ${ }^{(6)}$.

Our patient experienced headache before cognitive changes, confusion, and hearing loss, just like Susac has described. There was no visual complaint despite multiple arteriolar occlusions and vasculitis in both eyes. Fluorescein angiogram two months after diagnosis and treatment showed vasculitis improvement, without leakage, but occlusions remained. Fortunately, our patient suffered no visual impairment and no recurrence after three months follow-up. There is no way to know if it was due to prompt and correct therapy or
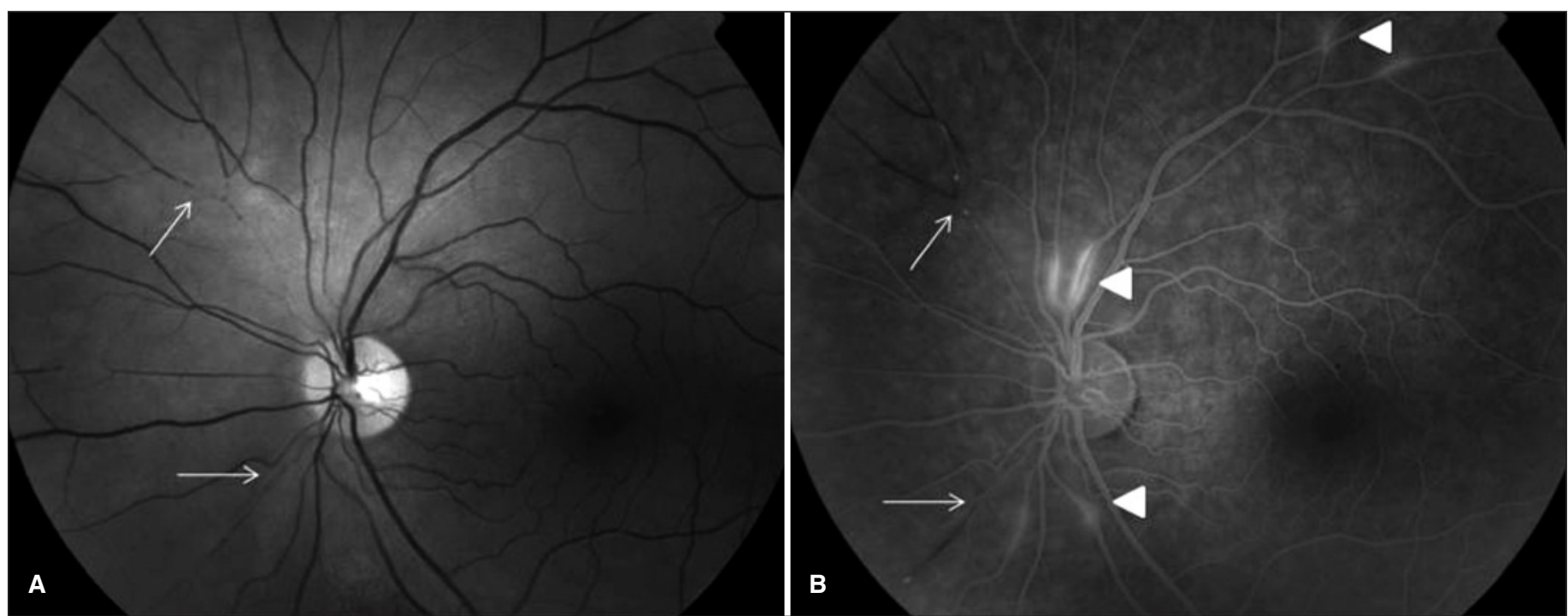

Figure 1 - Fundus photographs of the patient with Susac's syndrome before diagnosis. A) Left eye, red free photograph shows branch retinal arteria occlusions (arrows); B) Fluorescein angiogram of the left eye revealed multiple retinal arteriolar obstructions (arrows), and focal areas of arterial wall hiperfluorescence (arrowheads). 

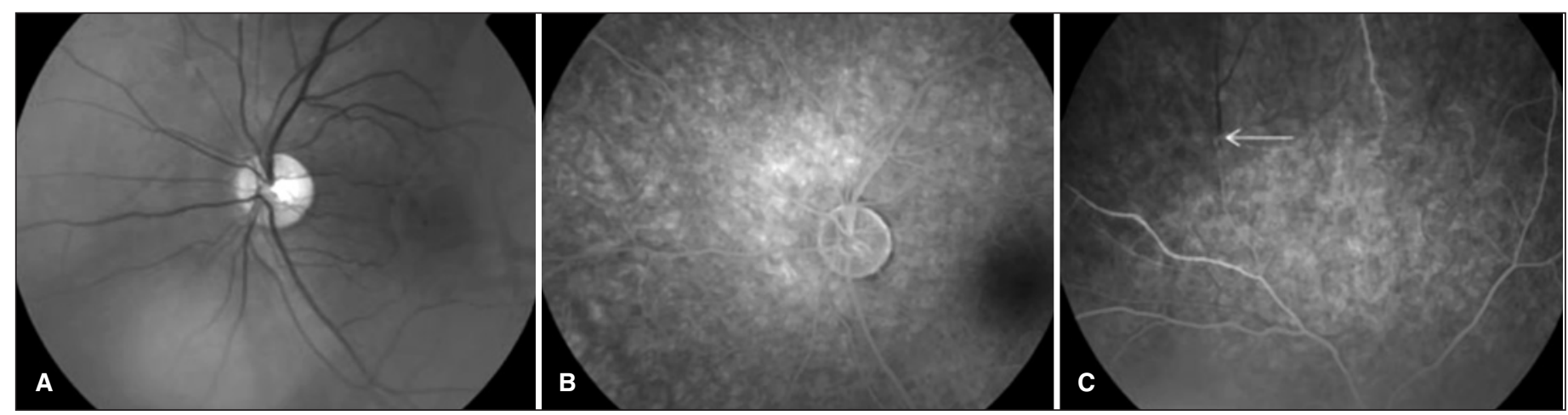

Figure 2 - Fundus photographs of the patient with Susac's syndrome two months after diagnosis. A) Left eye, red free photograph shows arteriolar occlusions improvement; B) Fluorescein angiogram of the left eye revealed arteriolar vasculitis improvement; C) Persistance of some peripheral arteriolar occlusions (arrows)

natural disease course ${ }^{(9)}$. It's important for ophthalmologists to be aware that recurrent branch arterioles occlusions may develop months to years from first crisis, leading to visual field impairment and sometimes comprising central vision ${ }^{(4)}$.

Neurologists are usually responsible for diagnosing this disease in consequence of pronounced mental state of these patients. The diagnosis is usually difficult. In a suspected case is important to rule out connective tissue disorder, procoagulant state, or infectious disease ${ }^{(1)}$. There is no entirely specific feature of Susac syndrome. Characteristic findings on brain MR image, ophthalmologic examination and audiogram should facilitate the diagnosis. Encephalopathic symptoms may obscure initial visual and auditory complaints, making diagnosis even more difficult ${ }^{(7)}$. It is recommended that any unexplained encephalopathy, predominantly involving the white matter, a neuro-ophthalmologist or retinal specialist should evaluate the patient ${ }^{(4)}$. In these cases, fluorescein angiography is extremely useful and will often show branch retinal arterial occlusions as well as the pathognomonic multifocal fluorescence of branch arterioles ${ }^{(10)}$.

Susac syndrome differential diagnosis is vast. This disease can mimic several others diseases, being frequently misdiagnosed $^{(4)}$. Ophthalmologic examination is extremely important to confirm diagnosis, differentiating this disease from others systemic illnesses such as multiple sclerosis, migraine, Behcet's disease, systemic lupus erythematosus, acute and chronic encephalitis, thromboembolic stroke ${ }^{(9)}$.

There is no consensus on treatment of Susac syndrome. It is difficult to evaluate the results of treatment in consequence to its tendency to improve spontaneously ${ }^{(4)}$. Recently Susac et al. published preliminary recommendations about treatment, including pulse of methylprednisolone, intravenous immunoglobulin, oral prednisone and cyclosphosphamide ${ }^{(8)}$. Our patient showed great improvement after treatment, but it is too early to tell if this treatment will lead to complete remission.

Susac syndrome has been considered rare, but it is probably more common than previously thought ${ }^{(4)}$. A high index of suspicion leading to early recognition and treatment is important to attempt minimization of persistent neurological, visual and audiologic impairment, and ophthalmologic examination play a important role.

\section{RESUMO}

Paciente masculino de 29 anos foi admitido em pronto-socorro com quadro de cefaléia progressiva há 10 dias seguida de náuseas. Durante internação evoluiu com letargia, redução do nível de consciência e hipoacusia bilateral. Exame oftalmológico e angiofluoresceinografia evidenciaram vasculite retiniana. Este achado foi essencial para o diagnóstico de síndrome de Susac, uma patologia rara caracterizada por vasculopatia de retina, encéfalo e cóclea. Tratamento imunossupressor foi instituído, prevenindo sequelas graves da doença.

Descritores: Vasculite retiniana; Angiofluoresceinografia; Vasculite do sistema nervoso central; Perda auditiva neurossensorial; Relatos de casos [Tipo de publicação]

\section{REFERENCES}

1. Schwitter J, Agosti R, Ott P, Kalman A, Waespe W. Small infarctions of cochlear, retinal, and encephalic tissue in young women. Stroke. 1992;23(6):903-7.

2. Susac JO, Hardimann JM, Selhorst JB. Microangiopathy of the brain and retina. Neurology. 1979;29(3):313-6.

3. Skacel M, Bardy FB, Pereira MB, Mendes MHF. Síndrome de Susac: relato de caso. Arq Neuropsiquiatr. 2000;58(4):1128-32.

4. Susac JO. Susac's syndrome. AJNR Am J Neuroradiol. 2004;25(3):351-2.

5. Rennebohm RM, Egan RA, Susac JO. Treatment of Susac's Syndrome. Curr Treat Options Neurol. 2008;10(1):67-74.

6. Petty GW, Engel AG, Younge BR, Duffy J, Yanagihara T, Lucchinetti CF, et al. Retinocochleocerebral vasculopathy. Medicine (Baltimore). 1998;77(1):12-40. Review.

7. Mala L, Bazard MC, Berrod JP, Wahl D; Raspiller A. Petits infarctus rétiniens, cochléaires et cérébraux du sujet jeune, ou SICRET syndrome ou syndrome de Susac. J Fr Ophtalmol. 1998;21(5):375-80.

8. Susac JO, Egan RA, Rennebohm RM, Lubow M. Susac's syndrome: 1975-2005 microangiopathy/autoimmune endotheliopathy. J Neurol Sci. 2007;257(1-2):270-2.

9. Do TH, Fisch C, Evoy F. Susac syndrome: report of four cases and review of the literature. AJNR Am J Neuroradiol. 2004;25(3):382-8.

10. Martinet N, Fardeau C, Adam R, Bodaghi B, Papo T, Piette JC, Lehoang P. Fluorescein and indocyanine green angiographies in Susac syndrome. Retina. 2007;27(9):1238-42. 